\title{
Enhancement of agronomic traits and yield of rice var. ADT 43 grown in typic ustifluvent soil through silicon fertilization
}

\author{
Arthi, V \\ Adhiyamaan College of Agriculture and Research, Krishnagiri (Tamil Nadu), India \\ M. V. Sriramachandrasekharan* iD \\ Department of Soil Science and Agricultural Chemistry, Faculty of Agriculture, Annamalai \\ University, Annamalainagar (Tamil Nadu), India \\ R. Manivannan \\ Department of Soil Science and Agricultural Chemistry, Faculty of Agriculture, Annamalai \\ University, Annamalainagar (Tamil Nadu), India \\ Arumugam Shakila \\ Department of Horticulture, Faculty of Agriculture, Annamalai University, Annamalainagar \\ (Tamil Nadu), India \\ *Corresponding author: Email: ramuthrat@gmail.com
}

\section{Article Info}

https://doi.org/10.31018/

jans.v13i3.2803

Received: June 28, 2021

Revised: September 2, 2021

Accepted: September 7, 2021

\section{How to Cite}

Arthi, V. et al. (2021). Enhancement of agronomic traits and yield of rice var. ADT 43 grown in typic ustifluvent soil through silicon fertilization. Journal of Applied and Natural Science, 13(3), 1052 - 1058. https://doi.org/10.31018/jans.v13i3.2803

\begin{abstract}
Rice is a rich accumulator of silicon and its supply is essential for the growth and economic yield of rice. Hence, a field experiment was conducted in sandy clay loam soil belonging to Padugai series (Typic ustifluvent) at farmers holding in Kuttalam block, Mayiladuthurai district, Tamil Nadu to assess the role of silicon in improving agronomic characters and yield of rice ADT 43, Oryza sativa. The treatments included $\mathrm{T}_{1}$ - Recommended dose of fertilizer (RDF), $\mathrm{T}_{2}-\mathrm{RDF}+$ Potassium silicate (FS) $0.25 \%, \mathrm{~T}_{3}-\mathrm{RDF}+\mathrm{FS}-0.50 \%, \mathrm{~T}_{4}-\mathrm{RDF}+\mathrm{FS}-1.00 \%, \mathrm{~T}_{5-}-\mathrm{RDF}+\mathrm{FS}-0.25 \%, \mathrm{~T}_{6}-\mathrm{RDF}+\mathrm{FS}-0.50 \%, \mathrm{~T}_{7-}-\mathrm{RDF}+\mathrm{FS}-1.00 \%$, $\mathrm{T}_{8}-\mathrm{RDF}+\mathrm{SA}-50 \mathrm{~kg} \mathrm{ha}^{-1}, \mathrm{~T}_{9}-\mathrm{RDF}+\mathrm{SA}-100 \mathrm{~kg} \mathrm{ha}^{-1}$ and $\mathrm{T}_{10}-\mathrm{RDF}+\mathrm{SA}-150 \mathrm{~kg} \mathrm{ha}^{-1}$. From $\mathrm{T}_{2}$ to $\mathrm{T}_{4}$, the foliar spray was done at tillering stage and from $T_{5}$ to $T_{7}$, the foliar spray was done at tillering and panicle initiation stage. The silicon was applied through FS with the rice crop. The soil application of silicon relatively recorded higher growth and yield compared to foliar application. Besides improving different agronomic characters of the rice, the soil application of $50 \mathrm{~kg} \mathrm{Si} \mathrm{ha}^{-1}$ registered the highest grain yield $\left(6183.3 \mathrm{~kg} \mathrm{ha}^{-1}\right)$ and straw yield $\left(6740 \mathrm{~kg} \mathrm{ha}^{-1}\right)$ and was comparable with a single foliar spray of $1 \% \mathrm{Si}$. Growth and

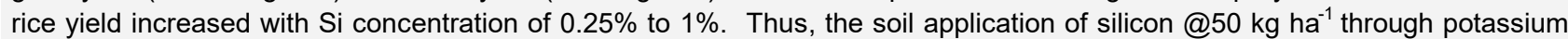
silicate is advocated to realize maximum rice yield.
\end{abstract}

Keywords: Growth, Rice, Silicon, Yield

\section{INTRODUCTION}

Rice is a staple food for about 800 million people in India. Rice holds a pivotal role in the food and livelihood security of people as it is a major food for more than sixty-five percent of the Indian population by bestowing approximately forty percent of total food grain. The area, production and productivity of rice in India is 43 Mha, 112 million tons (Mt) of milled rice and $2.6 \mathrm{t} \mathrm{ha}^{-1}$, respectively (Pathak et al., 2020). An effective soil nutrient management is an essential component of crop production, responsible for increasing and sustaining crop yields at high levels (Gerami et al., 2012). Due to continuous mono-cropping and/or intensive cultivation of cereal crops like rice, the soil Si concentration is depleted, which can be the main reason for declined rice yields (Mali and Aery, 2008). Silicon is indexed as a beneficial plant nutrient since the effect of its application on plant growth and yield is mostly conducted on silicon accumulator plants like rice and sugarcane (Ma and Takahashi 2002; Haynes, 2014). Silicon (Si) is ranked as the second-most abundant element (after oxygen) in the earth's crust, with nearly $29 \%$ mean content (Sommer et al., 2006). Silicon is absorbed as PAS (monosilicic acid) by rice plants in far larger quantities than the macronutrients. The potential of $\mathrm{Si}$ in improving crop yield has been demonstrated in many studies, especially under abiotic and biotic stress con- 
ditions (drought, heavy metals, salinity and pathogens (Farooq and Dietz, 2015). Silicon is beneficial to many crops when added to some soils as a fertilizer. Method of fertilizer application, including soil incorporation, topdressing and foliar application, is crucial as it affects nutrient accessibility. Silicon plays an important role in the plant growth and development and yield of rice (Patil et al., 2017; Singh et al., 2020; Chaiwong et al., 2021). Silicon exerts positive interaction with other applied nutrients and results in better agronomic performance and efficiency in yield response. Also, silicon spares no effort in providing tolerance to rice plants against abiotic and biotic stresses. Hence, silicon management is essential for increasing and sustaining rice productivity (Rao et al., 2017; Ramirez-Olvera et al., 2021). Therefore, a field trial was conducted to assess the impact of silicon applied through potassium silicate on rice grown in typic ustifluvent soil of Kuttalam block, Mayiladuthurai district Tamil Nadu.

\section{MATERIALS AND METHODS}

The field experiment was conducted in sandy clay loam soil belonging to Padugai series (Typic Ustifluvent) at farmers holding in Kuttalam block, Mayiladuthurai district, Tamil Nadu. The experimental soil had $\mathrm{pH}-7.25$, EC- $0.15 \mathrm{dSm}^{-1}$, soil organic carbon-3.5 g kg-1, $\mathrm{KMnO}_{4}$ $\mathrm{N}-265 \mathrm{~kg} \mathrm{ha}^{-1}$ (low), Olsen P- $18.4 \mathrm{~kg} \mathrm{ha}^{-1}$ (medium), $\mathrm{NH}_{4} \mathrm{OAc}-\mathrm{K}-228 \mathrm{~kg} \mathrm{ha}^{-1}$ (medium) and available silicon$25 \mathrm{mg} \mathrm{kg}^{-1}$. The treatment structure furnished is given in Table 1.

From $T_{2}$ to $T_{4}$, foliar spray was done at tillering stage and from $T_{5}$ to $T_{7}$, the foliar spray was done at tillering and panicle initiation stage. The recommended dose of 150:50:50 N, $\mathrm{P}_{2} \mathrm{O}_{5}$ and $\mathrm{K}_{2} \mathrm{O}$ ha $^{-1}$ through urea, superphosphate and muriate of potash was added uniformly to all the plots. The potassium silicate contains 22 per cent $\mathrm{Si}$ and 11 per cent $\mathrm{K}_{2} \mathrm{O}$. Foliar and soil application of silicon was applied as per the treatment schedule and the amount of potassium silicate-based on treatment was calculated. The amount of potassium supplied through potassium silicate was taken out while applying the recommended potassium dose to all the plots. A short-duration rice var ADT 43 was the test crop. The experiment was conducted in randomized block design (RBD) design with three replications. Randomly tagged five rice plants in each plot was used to measure plant height (Plant height was recorded by measuring the height of the plant from the surface of the soil to the tip of the top most leaf and expressed in centimetres), tiller count, LAI (leaf area index)( Williams, 1946), chlorophyll (Arnon 1949), yield characters (The number of panicles $\mathrm{m}^{-2}$ was counted by placing gradient at four different places in each plot, The well filled grains from representative panicles were differentiated into chaffs and grains and counted separately and recorded, one thousand grains were counted from the produce from each plot and weighed and expressed in grams and the ear head samples were collected from the tagged hill at harvest and the panicle length was measured and expressed in $\mathrm{cm}$. . At the time of harvest, grain and straw yield was recorded separately from each plot and expressed as $\mathrm{kg} / \mathrm{ha}$.

\section{RESULTS AND DISCUSSION}

\section{Growth characters}

On close perusal of the data furnished in Table 2 clearly showed significant $(P<0.05)$ effect of foliar and soil application of potassium silicate on the rice plant height, productive tillers, LAI, chlorophyll content, crop growth rate (CGR), relative growth rate (RGR) and net assimilation rate (NAR) over control. Soil application of silicon relatively recorded higher growth characters compared to foliar application. Among the treatments, the tallest plant $(86.5 \mathrm{~cm})$, maximum productive tillers hill $^{-1}(12.2)$, LAl ( 4.07), chlorophyll content $3.31 \mathrm{mg} / \mathrm{g}$ ), CGR ( $\left.8.51 \mathrm{~g} \mathrm{~m}^{-2} \mathrm{~d}^{-1}\right), \operatorname{RGR}\left(26.1 \mathrm{mg} \mathrm{g}^{-1} \mathrm{~d}^{-1}\right)$ and NAR $\left(2.63 \mathrm{~g} \mathrm{~m}^{-2} \mathrm{~d}^{-1}\right.$ ) was realised with soil application of 50 $\mathrm{kg} / \mathrm{ha}$ Si through potassium silicate and was comparable with foliar spray of $1 \% \mathrm{Si}$ sprayed at the tillering stage but superior to rest of the treatments. All growth characters declined when soil application of silicon increased from 50 to $150 \mathrm{~kg} \mathrm{ha}^{-1}$. Similarly, all the growth characters increased with foliar application of 0.25 to $1.0 \%$ silicon. However, when foliar spray was done twice, growth characters increased at 0.25 and $0.5 \%$ $\mathrm{Si}$. But when sprayed at $1 \%$ silicon, it declined. Plant height is one of the most important traits in determining the vigour and potential of any crop. The stature of the plant leads to structure and capacity to capture sunlight to assimilate photosynthesis by virtue of more leaves. Improved plant height due to silicon is associated with improved cell division, elongation and expansion. This was in harmony with the outcome of Yavarzadeh et al.

Table 1. Treatment structure of the present study.

\begin{tabular}{ll}
\hline $\mathrm{T}_{1}$ & RDF + No silicon \\
$\mathrm{T}_{2}$ & RDF + PS (FS) - 0.25\% @ TS \\
$\mathrm{T}_{3}$ & RDF + PS (FS) $-0.50 \%$ @ TS \\
$\mathrm{T}_{4}$ & RDF + PS (FS) - $\%$ @ TS \\
$\mathrm{T}_{5}$ & RDF + PS (FS) $-0.25 \%$ @ TS \& PI \\
$\mathrm{T}_{6}$ & RDF + PS (FS) - 0.50\% @ TS \& PI \\
$\mathrm{T}_{7}$ & RDF + PS (FS) - 1\% @ TS \& PI \\
$\mathrm{T}_{8}$ & RDF + PS (SA) - $50 \mathrm{~kg} \mathrm{ha}^{-1}$ \\
$\mathrm{~T}_{9}$ & RDF + PS (SA) - $100 \mathrm{~kg} \mathrm{ha}^{-1}$ \\
$\mathrm{~T}_{10}$ & RDF + PS (SA) - $150 \mathrm{~kg} \mathrm{ha}^{-1}$ \\
\hline
\end{tabular}

RDF-Recommended dose of fertilizer; PS- Potassium silicate, FS- Foliar spray, SA- soil application, TS - Tillering stage, PIPanicle initiation 
(2008) who revealed that enhanced plant height is ascribed to deposition of silicon on the rice plant tissue leading to erectness of the leaves and stem. In the present study, number of tillers per hill was significantly increased with the application of Si fertilizer, since tillering is the outcome of expanding axillary bud, and it is the result of the nutritional condition of the mother clump. Jawahar et al. (2015) also reported the beneficial role of Si fertilizer in increasing number of tillers per hill. A higher leaf area index could be due to the erectness of leaves. Silicon improves high interception of light by keeping leaves erect, thereby stimulating canopy photosynthesis in rice (Singh et al., 2005). Chlorophyll plays a role not only in the capacity but also in the efficiency of plant photosynthesis. Improvement in chlorophyll content due to silicon is due to reinforcement of the cell wall due to the deposit of silicon in the form of amorphous silica. Further erectness of the leaves and synthesis of chloroplast results in a higher chlorophyll concentration per unit area of leaf tissue (Cao et al.,2013). Foliar application of potassium silicate stimulated antioxidant superoxide dismutase activity and increased photosynthesis capacity and chlorophyll content in bent grass especially under a high fertilizer regime (Schmidt et al., 1999). Doaa et al. (2012) reported an increase in chlorophyll content in rice on the spraying of $5 \%$ potassium silicate. The crop growth rate is a unit increase in dry matter of crop on a daily basis, relative growth rate measures the increase in dry matter with a given amount of assimilating material at a given point of time and net assimilation rate measures the mean photosynthetic efficiency of leaves in a crop community. Ahmad et al. (2013) reported increased CGR, RGR and NAR on silicon addition. Anand Lokadal and Sreekanth (2018) also echoed a similar effect of silicon on rice var BPT 5204 growth cultivated in sandy soils of Bapatla, Andhra Pradesh.

\section{Yield attributes}

The various yield contributing characters were statistically significant at $5 \%$ level due to soil and foliar administration of silicon through potassium silicate over control (Table 3). The highest number of panicles $\mathrm{m}^{-2}$ (360), the highest number of grains panicle ${ }^{-1}(131)$, the highest number of filled grains panicle ${ }^{-1}$ (112), the lengthiest panicle $(16.7 \mathrm{~cm})$ and maximum 1000 grain weight $(17 \mathrm{~g})$ was noticed with of $50 \mathrm{~kg} \mathrm{Si} \mathrm{ha}^{-1}$ followed by foliar spray of $1 \%$ silicon applied at tillering stage. But superior to rest of the treatments. Foliar application of silicon twice recorded higher yield attributes compared to single spray. Soil application of $50 \mathrm{~kg} \mathrm{Si} \mathrm{ha}^{-1}$ and single foliar spray of silicon at $1 \%$ caused 11 and $9.8 \%$ (number of panicles $\mathrm{m}^{-2}$ ), 9.2 and $7.5 \%$ (number of grains panicle ${ }^{-1}$ ), 11 and $8.9 \%$ (number of filled grains panicle ${ }^{-1}$ ), 5.7 and $3.8 \%$ (panicle length) and 7.6 and $6.9 \%$ (1000 grain weight). Availability of plantavailable silicon and a steady supply of silicon in the form of silicic acid for a longer period to crop and promotional effect of silicon with other nutrients resulted in better photosynthetic activity by the crop and led to

Table 2. Effect of potassium silicate on growth components of rice var ADT 43

\begin{tabular}{|c|c|c|c|c|c|c|c|}
\hline Treatments & $\begin{array}{l}\text { Plant } \\
\text { Height } \\
\text { (cm) } \\
\text { at harvest }\end{array}$ & $\begin{array}{l}\text { Produc- } \\
\text { tive tillers } \\
\text { hill }^{-1}\end{array}$ & $\begin{array}{l}\text { LAI } \\
\text { at } \\
\text { P.I } \\
\text { Stage }\end{array}$ & $\begin{array}{l}\text { Chlorophyll } \\
(\mathrm{mg} / \mathrm{g}) \\
\text { at P.I stage }\end{array}$ & $\begin{array}{l}\text { CGR } \\
\left(\mathrm{g} \mathrm{m}^{-2} \mathrm{~d}^{-1}\right) \\
\text { at } 30-60 \text { DAT }\end{array}$ & $\begin{array}{l}\text { RGR } \\
\left(\mathrm{mg} \mathrm{g}^{-1} \mathrm{~d}^{-1}\right) \\
\text { at } 30-60 \text { DAT }\end{array}$ & $\begin{array}{l}\text { NAR } \\
\left(g^{-2} d^{-1}\right) \\
\text { at } 30-60 \\
\text { DAT }\end{array}$ \\
\hline $\mathrm{T}_{1}-\mathrm{RDF}$ (Control) & 83.8 & 11.2 & 3.18 & 3.01 & 7.15 & 23.7 & 2.22 \\
\hline $\begin{array}{l}\mathrm{T}_{2}-\mathrm{RDF}+\mathrm{PS}(\mathrm{FS})- \\
0.25 \% @ \mathrm{TS}\end{array}$ & 84.2 & 11.7 & 3.65 & 3.15 & 7.38 & 24.2 & 2.33 \\
\hline $\begin{array}{l}T_{3}-\mathrm{RDF}+\mathrm{PS}(\mathrm{FS})- \\
0.50 \% \text { @ TS }\end{array}$ & 85.1 & 12.0 & 3.72 & 3.20 & 7.67 & 24.6 & 2.35 \\
\hline $\mathrm{T}_{4}-\mathrm{RDF}+\mathrm{PS}(\mathrm{FS})-1 \%$ & 85.9 & 12.2 & 3.87 & 3.29 & 8.21 & 25.1 & 2.46 \\
\hline $\begin{array}{l}\mathrm{T}_{5}-\mathrm{RDF}+\mathrm{PS}(\mathrm{FS})- \\
0.25 \% @ \mathrm{TS} \& \mathrm{PI}\end{array}$ & 85.4 & 11.9 & 3.78 & 3.20 & 7.55 & 24.8 & 2.41 \\
\hline $\begin{array}{l}\mathrm{T}_{6}-\mathrm{RDF}+\mathrm{PS}(\mathrm{FS})- \\
0.5 \% @ \mathrm{TS} \& \mathrm{PI}\end{array}$ & 86.0 & 12.1 & 3.80 & 3.24 & 7.92 & 25.0 & 2.45 \\
\hline $\begin{array}{l}\mathrm{T}_{7}-\mathrm{RDF}+\mathrm{PS}(\mathrm{FS})-1 \% \\
@ \text { TS \& PI }\end{array}$ & 85.5 & 12.0 & 3.81 & 3.27 & 7.71 & 24.9 & 2.46 \\
\hline$T_{8}-R D F+P S(S A)-50$ & 86.5 & 12.2 & 4.07 & 3.31 & 8.51 & 26.1 & 2.63 \\
\hline $\mathrm{T}_{9}-\mathrm{RDF}+\mathrm{PS}(\mathrm{SA})-$ & 86.0 & 12.0 & 4.03 & 3.29 & 8.44 & 25.8 & 2.60 \\
\hline $\begin{array}{l}T_{10}-\mathrm{RDF}+\mathrm{PS}(\mathrm{SA})- \\
150 \mathrm{~kg} \mathrm{ha}^{-1}\end{array}$ & 85.7 & 11.9 & 3.99 & 3.28 & 8.21 & 25.7 & 2.56 \\
\hline$S E_{d}$ & 0.47 & 0.43 & 0.06 & 0.05 & 0.05 & 0.14 & 0.03 \\
\hline CD @ 5\% & 1.00 & 0.90 & 0.13 & 0.11 & 0.12 & 0.30 & 0.08 \\
\hline
\end{tabular}


higher yield attributes. Panicle formation is directly related to the number of productive tillers, resulting in a higher number of panicles per unit area. It was confirmed by a positive correlation between productive tillers with a number of panicles $\mathrm{m}^{-2}\left(r=0.835^{\star *}\right)$ and a number of grains panicle ${ }^{-1}\left(r=0.924^{* *}\right)$. Increased filled grains were due to better assimilates of carbohydrates in a panicle. An increase in the number of spikelet's panicle $^{-1}$ of rice due to silicon addition was reported by Deivaseeno et al. (2020) and Mohammad et al. (2012). Higher test weight is attributed to better availability and translocation of nutrients as well as photosynthates from source to sink. Silicon has been reported to reduce the shattering of seeds in rice and increase the number and weight of filled grains (Seebold et al., 2000). An increase in 1000 grain weight could also be due to greater deposition of silicon in paleae and lemma (Balastra et al., 1989). Singh et al. (2006) and Ahmad et al. (2013) reported an increase in yield attributes through the foliar spray of $1 \%$ silicon, which they attribute due to better silicon nutrition of rice plant.

\section{Rice yield}

On close examination of data furnished in Table 4 showed significant $(P<0.05)$ impact of graded dose of foliar and soil application of silicon through potassium silicate on grain and straw yield over control. The grain yield ranged from 5283 to $6183 \mathrm{~kg} \mathrm{ha}^{-1}$ and straw yield ranged from 5653 to $6740 \mathrm{~kg} \mathrm{ha}^{-1}$. Soil application of 50 $\mathrm{kg} \mathrm{Si} \mathrm{ha}^{-1}$ recorded the highest grain yield $(6183 \mathrm{~kg}$ ha$\left.{ }^{1}\right)$ and straw yield $\left(6740 \mathrm{~kg} \mathrm{ha}^{-1}\right)$. Foliar spray of silicon increased the grain yield from 5530 to $6133 \mathrm{~kg} \mathrm{ha}^{-1}$ over control (5283 kg ha-1) and straw yield from 6028 to $6747 \mathrm{~kg} \mathrm{ha}^{-1}$ over control (5653 kg ha-1). Twice foliar spray of silicon recorded higher rice yield compared to single spray except for foliar spray @ 1\%. Among the foliar spray, application @ 0.5 and $0.25 \%$ twice recorded higher rice yield compared to their single spray. But when $1.0 \%$ Si foliar spray was applied twice, it reduced the yield. Sol application of $50 \mathrm{~kg} \mathrm{Si} \mathrm{ha}^{-1}$ was comparable with foliar spray of $\mathrm{Si} @ 1 \%$ applied at tillering stage. Per cent increase in grain yield ranged from 4.7 to 17 and straw yield ranged from 6.6 to 19.4 due to

Table 3. Effect of potassium silicate on yield attributes of rice var. ADT 43

\begin{tabular}{|c|c|c|c|c|c|}
\hline Treatments & $\begin{array}{l}\text { Number of } \\
\text { panicles } \mathrm{m}^{-2}\end{array}$ & $\begin{array}{l}\text { Number of } \\
\text { grains panicle }^{-1}\end{array}$ & $\begin{array}{l}\text { Panicle } \\
\text { length }(m)\end{array}$ & $\begin{array}{l}1000 \text { grain } \\
\text { weight }(g)\end{array}$ & $\begin{array}{l}\text { Number of filled } \\
\text { grains panicle }^{-1}\end{array}$ \\
\hline $\mathrm{T}_{1}-\mathrm{RDF}$ (Control) & 325 & 120 & 15.8 & 15.8 & 101 \\
\hline $\mathrm{T}_{2}-\mathrm{RDF}+\mathrm{PS}(\mathrm{FS})-0.25 \% @ \mathrm{TS}$ & 329 & 123 & 16.0 & 16.0 & 103 \\
\hline $\mathrm{T}_{3}-\mathrm{RDF}+\mathrm{PS}(\mathrm{FS})-0.50 \% @ \mathrm{TS}$ & 341 & 125 & 16.1 & 16.7 & 105 \\
\hline $\mathrm{T}_{4}-\mathrm{RDF}+\mathrm{PS}(\mathrm{FS})-1 \% @ \mathrm{TS}$ & 357 & 129 & 16.4 & 16.9 & 110 \\
\hline $\mathrm{T}_{5}-\mathrm{RDF}+\mathrm{PS}(\mathrm{FS})-0.25 \% @ \mathrm{TS} \& \mathrm{PI}$ & 335 & 125 & 16.2 & 16.3 & 105 \\
\hline $\mathrm{T}_{6}-\mathrm{RDF}+\mathrm{PS}(\mathrm{FS})-0.50 \% @ \mathrm{TS} \& \mathrm{PI}$ & 348 & 127 & 16.4 & 16.5 & 107 \\
\hline $\mathrm{T}_{7}-\mathrm{RDF}+\mathrm{PS}(\mathrm{FS})-1 \% @ \mathrm{TS} \& \mathrm{PI}$ & 352 & 127 & 16.2 & 16.7 & 108 \\
\hline $\mathrm{T}_{8}-\mathrm{RDF}+\mathrm{PS}(\mathrm{SA})-50 \mathrm{~kg} \mathrm{ha}^{-1}$ & 360 & 131 & 16.7 & 17.0 & 112 \\
\hline $\mathrm{T}_{9}-\mathrm{RDF}+\mathrm{PS}(\mathrm{SA})-100 \mathrm{~kg} \mathrm{ha}{ }^{-1}$ & 355 & 126 & 16.4 & 16.8 & 110 \\
\hline$T_{10}-R D F+P S(S A)-150 \mathrm{~kg} \mathrm{ha}^{-1}$ & 352 & 125 & 16.3 & 16.7 & 107 \\
\hline$S E_{d}$ & 1.83 & 2.53 & 0.36 & 0.27 & 3.57 \\
\hline CD @ 5\% & 5.44 & 5.33 & 0.77 & 0.56 & 7.50 \\
\hline
\end{tabular}

Table 4. Effect of potassium silicate on grain and straw yield of rice var. ADT 43

\begin{tabular}{|c|c|c|c|c|}
\hline Treatments & $\begin{array}{l}\text { Grain yield } \\
\left(\mathrm{kg} \mathrm{ha}^{-1}\right)\end{array}$ & $\begin{array}{l}\text { Straw yield } \\
\left(\mathrm{kg} \mathrm{ha}^{-1}\right)\end{array}$ & $\begin{array}{l}\text { Per cent increase } \\
\text { over control (Grain) }\end{array}$ & $\begin{array}{l}\text { Per cent increase over } \\
\text { control (Straw) }\end{array}$ \\
\hline $\mathrm{T}_{1}-\mathrm{RDF}$ (Control) & 5283 & 5653 & - & - \\
\hline $\mathrm{T}_{2}-\mathrm{RDF}+\mathrm{PS}(\mathrm{FS})-0.25 \% @ \mathrm{TS}$ & 5530 & 6028 & 4.7 & 6.6 \\
\hline $\mathrm{T}_{3}-\mathrm{RDF}+\mathrm{PS}(\mathrm{FS})-0.50 \% @ \mathrm{TS}$ & 6067 & 6522 & 14.8 & 15.3 \\
\hline $\mathrm{T}_{4}-\mathrm{RDF}+\mathrm{PS}(\mathrm{FS})-1 \% @ \mathrm{TS}$ & 6133 & 6747 & 16.1 & 19.4 \\
\hline $\mathrm{T}_{5}-\mathrm{RDF}+\mathrm{PS}(\mathrm{FS})-0.25 \% @ \mathrm{TS} \& \mathrm{PI}$ & 5750 & 6210 & 8.8 & 9.9 \\
\hline $\mathrm{T}_{6}-\mathrm{RDF}+\mathrm{PS}(\mathrm{FS})-0.50 \% @ \mathrm{TS} \& \mathrm{PI}$ & 5983 & 6613 & 13.2 & 16.9 \\
\hline $\mathrm{T}_{7}-\mathrm{RDF}+\mathrm{PS}(\mathrm{FS})-1 \% @ \mathrm{TS} \& \mathrm{PI}$ & 5633 & 6197 & 6.6 & 9.6 \\
\hline $\mathrm{T}_{8}-\mathrm{RDF}+\mathrm{PS}(\mathrm{SA})-50 \mathrm{~kg} \mathrm{ha}^{-1}$ & 6183 & 6740 & 17.0 & 19.2 \\
\hline $\mathrm{T}_{9}-\mathrm{RDF}+\mathrm{PS}(\mathrm{SA})-100 \mathrm{~kg} \mathrm{ha}^{-1}$ & 5733 & 6192 & 8.5 & 9.5 \\
\hline $\mathrm{T}_{10}-\mathrm{RDF}+\mathrm{PS}(\mathrm{SA})-150 \mathrm{~kg} \mathrm{ha}^{-1}$ & 5567 & 6123 & 5.4 & 8.3 \\
\hline$S E_{d}$ & 50.0 & 98 & & \\
\hline CD @ 5\% & 149 & 205 & & \\
\hline
\end{tabular}


various treatment and the highest per cent increase in grain yield was noticed with soil application of $50 \mathrm{~kg} \mathrm{Si}$ ha $^{-1}$ (17.0) followed by single spray @ 1\% Si applied at tillering stage (16.1). The lowest response was noticed with foliar spray of Si @ 0.25 per cent applied at tillering stage. Silicon effects on yield are related to the deposition of the element under the leaf epidermis, which results in physical mechanism of defense, production of phenols which stimulate phytoalexin production, reducing lodging, decreases transpiration losses and increases photosynthetic capacity of rice plant as reported by Ahmad et al., (2013).

The enhanced grain yield could be due to increased large leaf area and high chlorophyll content, which might have accumulated more photosynthates and produced higher biological yield. In the present study, soil application of $50 \mathrm{~kg} \mathrm{Si} /$ ha registered maximum LAI and chlorophyll. Higher rice yield due to silicon inclusion is associated with increased spikelet's panicle-1, 1000 grain weight, and panicle length. The silicon application improved significantly yield attributes. This was corroborated by the equation of quadratic relationship found between rice yields with various attributes viz., number of panicles $/ \mathrm{m}^{2}$, number of grains/panicle, number of filled grains/panicle, panicle length and 1000 grain weight (Fig. 1). The equation found that all of them positively contributed to higher yield. But it was number of grains panicle-1 that contributed much to grain yield (70.8\%) followed by 1000 grain weight (57.1\%), panicle length (56.2), number of filled grains (49.0\%) and number of panicles $\mathrm{m}^{-2}(43.4 \%)$. Gerami et al. (2012), Yogendra et al. (2014), Singh et al. (2020) and Siregar et al. (2021) reported enhanced rice grain yield due to Si fertilization in silicon deficient soil and they attributed to an increase in DMP and yield attributes. The present study also witnessed higher DMP and yield attributes due to silicon fertilization and eventually it had contributed to higher yield as witnessed by earlier workers

\section{Conclusion}

The field experiment conducted on the response of rice var ADT 43 to soil and foliar application of silicon through potassium silicate indicated that the rice responded well to silicon fertilization administered either through soil or foliar techniques. From the present study, it can be concluded that soil application of $50 \mathrm{~kg}$ Si/ha or foliar spray of Si@ 1\% sprayed at tillering

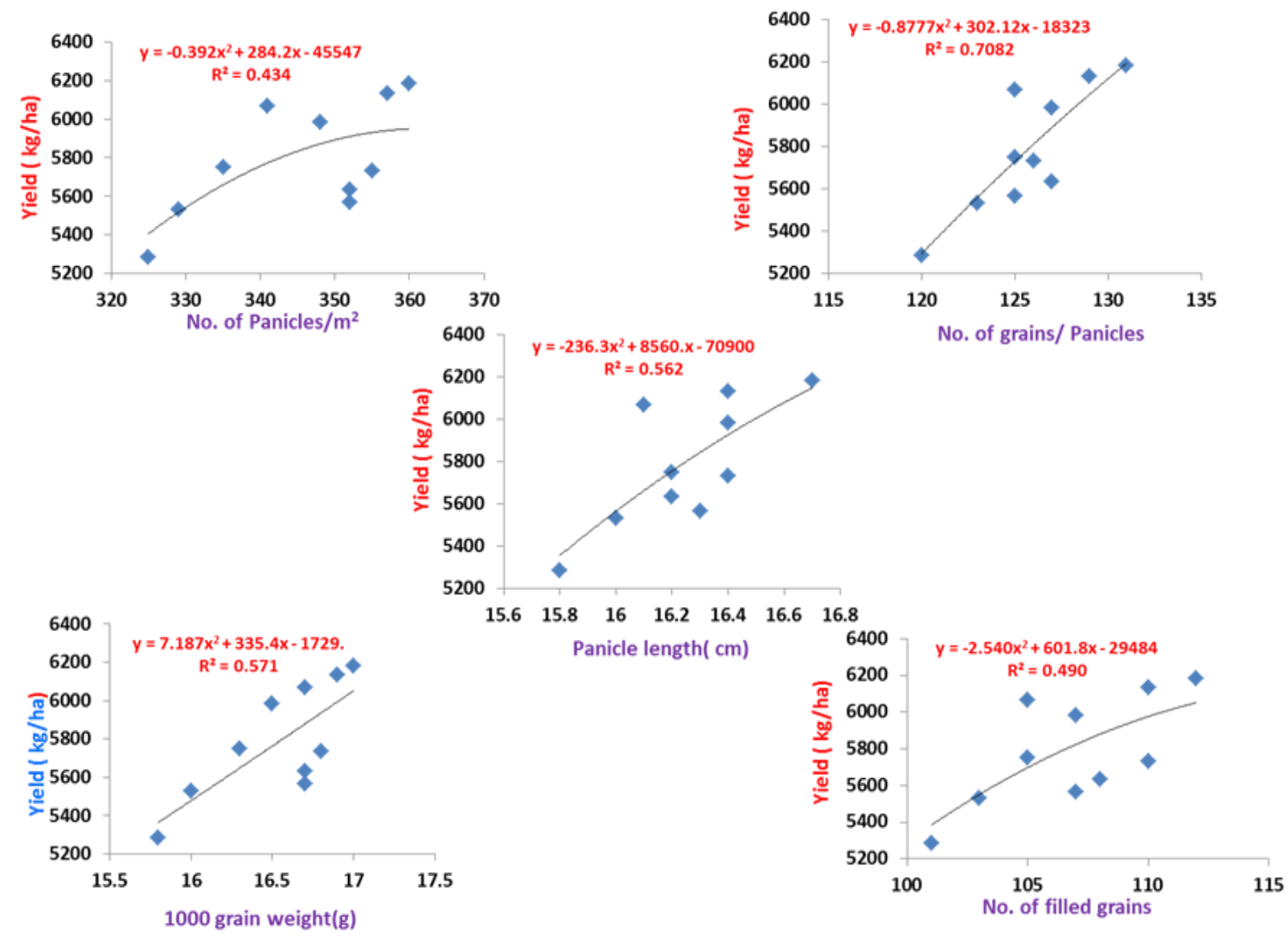

Fig.1. Showing quadratic relationship between grain yields and the yield attributes of rice var. ADT 43 
stage through potassium silicate enhanced the growth and yield of rice grown in Kuttalam block, Mayiladuthurai district, Tamil Nadu. The experiment has to be conducted in other rice-growing soils also to validate the result emanated from the present study before it is passed on to farmers for adoption.

\section{ACKNOWLEDGEMENTS}

The first author expresses her gratitude and thanks to the Head of the Department of Soil Science and Agricultural Chemistry, Faculty of Agriculture, Annamalai University, Annamalai (Tamil Nadu) for extending all the necessary help for the conduct of experiment and laboratory analysis

\section{Conflict of interest}

The authors declare that they have no conflict of interest.

\section{REFERENCES}

1. Ahmad, A.M., Afzal, A.U.H., Ahamad, A. \& Tahir, M. (2013). Effect of foliar application of silicon on yield and quality of rice (Oryza sativa). Cercetari Agronomica in Moldova, 3(155), 21-28.

2. Anand Lokadal \& Sreekanth, B. (2018). Effect of soil application of silicon on growth and yield attributes of rice (Oryza sativa L.). International Journal of Current .Microbiology and Applied Science, 7(11), 838-844 https://doi.org/10.20546/ijcmas.2018.711.099

3. Balastra, M.L.F., Perez, C.M., Juliano, B.O. \& Villreal, P. (1989). Effect of silica level on some properties of Oryza sativa straw and hult. Canadian Journal of Botany, 67, 2356-2363

4. Cao, B.L., Xu, K. \& Shi, J. (2013). Effects of silicon on growth, photosynthesis and transpiration of tomato. Plant Nutrition and Fertilizer Science, 19(2), 354-360. http:// dx.doi.org/10.1155/2014/718716

5. Chaiwong, N., Rerkasem, B., Pusadeea, T., \& PromuThai, C. (2021). Silicon application improves caryopsis development and yield in rice. J Sci Food Agric.101, 220228 DOI 10.1002/jsfa.10634

6. Deivaseeno Dorairaj., Mohd Razi Ismail., Uma Rani Sinniah. \& Kar Ban Tan. (2020). Silicon mediated improvement in agronomic traits, physiological parameters and fibre content in Oryza sativa. Acta Physiologiae Plantarum 42, 38 (1-11) https://doi.org/10.1007/s11738-020-3024-5

7. Doaa, M., Abou Basha El-Sayed, A.B.B. \& El-Alia, H.I. (2012). Effect of nitrogen levels, diatomite and potassium silicate application on yield and chemical composition of wheat (Triticum aestivum L.) plants. World Applied Sciences Journal, 25(8), 1217-1221

8. Farooq, M.A. \& Dietz, K.J. (2015). Silicon as versatile player in plant and human biology: Overlooked and poorly understood. Frontiers in Plant Science. 6 1-14 https:// doi.org/10.3389/fpls.2015.00994

9. Gerami, M., Fallah, A., Khatami, A. \& Moghadam, M.R. 2012. Study of potassium and sodium silicate on the morphological and chlorophyll content on the rice plant in pot experiment (Oryza sativa L.).International. Journal Agricultural Crop Sciences, 4(10), 68-661 http://ijag cs.com/.../658-661.pdf

10. Haynes, R. J. (2014). A contemporary overview of silicon availability in agricultural soil. Journal of Plant Nutrition and Soil Science, 177 (6), 831-844 https://doi.org/10.10 02/jpln.201400202

11. Jawahar, S., Vijayakumar, D., Bommera, R. \& Jain, N. (2015). Effect of silixol granules on growth and yield of rice. International Journal Current Research Academic Reviews, 3: 168-174.

12. Ma, J.F., \& Takahashi, E. (2002). Soil, Fertilizer, and Plant Silicon Research in Japan. Amsterdam-Boston-LondonNew York-Oxford, Paris-San Diego-San FranciscoSingapore-Sydney-Tokyo: Elsevier.

13. Mali, M. \& Aery, N.C. (2008). Silicon effects on nodule growth, dry matter production, and mineral nutrition of cowpea (Vigna unguiculata). Journal Plant Nutrition Soil Science, 171, 835-40https://doi.org/10.1002/jpln.2007 00362

14. Mohammad Reza Khabbazar., Ali Abdzad Gohari., Arash Kahonok., \& Reza Ebrahimpour Dargah. (2012). Response of rice varieties to different levels of silica and potassium in North Iran. Intl. J. Agri. Crop Sci., 4(18), 1385-1390.

15. Pathak, H., Tripathi, R., Jambhulkar, N.N., Bisen, J.B. \& Panda, B.B. (2020). Eco-regional Rice Farming for Enhancing Productivity, Profitability and Sustainability. NRRI Research Bulletin No. 22, ICAR-National Rice Research Institute, Cuttack 753006, Odisha, India. pp 28

16. Patil, A.A., Durgud, A.G., Pharande, A.L., Kadlag, A.D. \& Nimbalkar, C.A. (2017). Effect of calcium silicate as a silicon source on growth and yield of rice plants. International Journal of Chemical Studies. 5 (6), 545-549

17. Rao, G.B., Poornima Yadav. \& Elizabeth K Syriac. (2017). Silicon nutrition in rice: A review. Pharmacognosy Journal 6, 390-392

18. Ramírez-Olvera, S.M., Trejo-Téllez, L.I., Gómez-Merino, F.C., Ruíz-Posadas, L.d.M., Alcántar-González, E.G., \& Saucedo-Veloz, C. Silicon Stimulates (2021) Plant Growth and Metabolism in Rice Plants under Conventional and Osmotic Stress Conditions. Plants, 10, 777. https:// doi.org/10.3390/plants10040777

19. Schmidt, R.E., Zhang, X. \& Chalmers, D.R. (1999). Response of photosynthesis and superoxide dismutase to silica applied to creeping bent grass grown under two irrigation systems. Soil Biology and Biochemistry, 27, 1363-1370 https://doi.org/10.1080/01904169909365752

20. Seebold, K.W, Datnoff, L.E., Correavictoria, F.J., Kucharek, T.A. \& Snyder, G.H. (2000). Effect of silicon rate and host resistance on blast, scald, and yield of upland rice. Plant Disease. 84(8), 871-876 doi: 10.1094/ PDIS.2000.84.8.871.

21. Singh, K., Singh, R., Singh, J.B., Singh, Y. \& Singh, K.K. (2006). Effect of level and time of silicon application on growth, yield and its uptake by rice (Oryza sativa L.). Indian Journal of Agricultural Sciences, 76(7), 410-413.

22. Singh, K.Y., Singh, C.S., Singh, R., Singh, K.K., Singh, A. \& Singh, K. (2005). Silicon nutrition in rice. Fertilizer News 50(2), 41-48

23. Singh, V., Singh, V., Singh, S. \& Richa Khanna. (2020). Effect of zinc and silicon on growth and yield of aromatic rice (Oryza Sativa) in North-Western Plains of India. Jour- 
nal of Rice Research Development 3(1),82-86 DOI: 10.36959/973/424

24. Siregar, A.F.I., Sipahutar, A., Anggria L Husnain., \& Yufdi, M.F. (2021). Improving rice growth and yield with silicon addition in Oxisols. IOP Conf. Ser.: Earth Environ. Sci. 648, 012202

25. Sommer, M., Kaczorek, D., Kuzyahoy, Y., \& Breuer, J. (2006). Silicon pools and fluxes in soils and landscapes-A Review. Journal Plant Nutrition Soil Sciences, 169,310329 https://doi.org/10.1002/jpln.200690016
26. Yavarzadeh, M.R., Gavali, R.S., \& Dhumal, K.N. (2008). Impact of soil application of fly ash on growth and yield of wheat. Journal of Maharashtra Agricultural University, 33 (2), 158-160.

27. Yogendra, N.D., Kumara, B.H., Chandrashekar, N., Prakash, N.B., Anantha, M.S., \& Jeyadeva, H.M. (2014). Effect of silicon on real time nitrogen management in a rice ecosystem, African Journal of Agricultural Research, 9(9), pp. $831-840$ 